\title{
Potential Neuroprotective and Anti-Apoptotic Properties of a Long-Lasting Stable Analog of Ghrelin: an In Vitro Study Using SH-SY5Y Cells
}

\author{
A. POPELOVÁ ${ }^{1}$, A. KÁKONOVÁ ${ }^{1}$, L. HRUBÁ ${ }^{1}$, J. KUNES̆ ${ }^{1,2}$, L. MALETÍNSKÁ ${ }^{1}$, \\ B. ŽELEZNÁ ${ }^{1}$
}

${ }^{1}$ Institute of Organic Chemistry and Biochemistry of the Czech Academy of Sciences, Prague, Czech Republic, ${ }^{2}$ Institute of Physiology of the Czech Academy of Sciences, Prague, Czech Republic

Received September 13, 2017

Accepted October 9, 2017

On-line January 5, 2018

\section{Summary}

Neurodegenerative disorders, such as Alzheimer's disease (AD) and Parkinson's disease (PD), are increasing in prevalence. Currently, there are no effective and specific treatments for these disorders. Recently, positive effects of the orexigenic hormone ghrelin on memory and learning were demonstrated in mouse models of $A D$ and PD. In this study, we tested the potential neuroprotective properties of a stable and long-lasting ghrelin analog, $\mathrm{Dpr}^{3}$ ghrelin ( $\mathrm{Dpr}^{3} \mathrm{ghr}$ ), in SH-SY5Y neuroblastoma cells stressed with $1.2 \mathrm{mM}$ methylglyoxal (MG), a toxic endogenous by-product of glycolysis, and we examined the impact of $\mathrm{Dpr}^{3} \mathrm{ghr}$ on apoptosis. Pre-treatment with both $10^{-5}$ and $10^{-7} \mathrm{M} \mathrm{Dpr}^{3} \mathrm{ghr}$ resulted in increased viability in SH-SY5Y cells (determined by MTT staining), as well as reduced cytotoxicity of MG in these cells (determined by LDH assay). $\mathrm{Dpr}^{3} \mathrm{ghr}$ increased viability by altering pro-apoptotic and viability markers: Bax was decreased, $\mathrm{BCl}-2$ was increased, and the $\mathrm{Bax} / \mathrm{Bcl}-2$ ratio was attenuated. The ghrelin receptor GHS-R1 and $\mathrm{Dpr}^{3}$ ghr-induced activation of PBK/Akt were immuno-detected in SH-SY5Y cells to demonstrate the presence of GHS-R1 and GHS-R1 activation, respectively. We demonstrated that $\mathrm{Dpr}^{3} \mathrm{ghr}$ protected SH-SY5Y cells against MG-induced neurotoxicity and apoptosis. Our data suggest that stable ghrelin analogs may be candidates for the effective treatment of neurodegenerative disorders.

\section{Key words}

Ghrelin - SH-SY5Y cells • Methylglyoxal cytotoxicity • Neuroprotection • Apoptosis

\section{Corresponding author}

L. Maletínská, Institute of Organic Chemistry and Biochemistry of the Czech Academy of Sciences, Flemingovo nám. 2, 16610 Prague 6, Czech Republic. E-mail: maletin@uochb.cas.cz

\section{Introduction}

For the study of neurodegenerative diseases such as Alzheimer's (AD) and Parkinson's (PD) disease, proper in vitro systems are necessary. When exposed to neurotoxic agents such as methylglyoxal (MG), neuroblastoma cells, such as the SH-SY5Y cell line, are useful in evaluating the potential of neuroprotective drugs (Amicarelli et al. 2003, Sharma et al. 2014).

In SH-SY5Y cells, MG toxicity causes increases in reactive oxygen species, decreases in intracellular ATP and mitochondrial potential, and, ultimately, loss of mitochondrial integrity (de Arriba et al. 2007). Furthermore, MG-induced apoptosis increases levels of pro-apoptotic Bax protein and caspase-3, while levels of the pro-viability protein $\mathrm{Bcl}-2$ are attenuated (Tajes et al. 2014). Caspase- 3 is critical for the onset of apoptosis and is linked to enhanced synaptic failure, an early AD event (D'Amelio et al. 2011).

Recently, lactate dehydrogenase (LDH) assays showed that toxic effects of MG in SH-SY5Y cells are decreased by liraglutide (Sharma et al. 2014), an analog of insulin-secreting and anorexigenic glucagon-like peptide-1 (GLP-1). Tetrazolium dye (XTT) assays 
showed that liraglutide enhances SH-SY5Y cell viability after MG exposure. Liraglutide activates GLP-1 receptor signaling pathways $\mathrm{PKB} / \mathrm{Akt}$ and MAPK/ERK and attenuates the pro-apoptotic proteins Bax and Bik; it also enhances activation of the anti-apoptotic protein 90RSK (Sharma et al. 2014).

Interestingly, MAPK/ERK and PKB/Akt pathways induced by liraglutide are also activated by the orexigenic peptide ghrelin (Shi et al. 2017). Moreover, a neuroprotective mechanism similar to that of liraglutide has also been suggested for ghrelin: increased levels of the pro-viability protein Bcl-2 and decreased levels of the pro-apoptotic protein $\mathrm{Bax}$ and the ratio of $\mathrm{Bax} / \mathrm{Bcl}-2$, which is regarded as an apoptosis marker (Salakou et al. 2007). Bcl-2 directly binds to Bax forming a non-active heterodimer and blocking formation of the active pro-apoptotic Bax homodimer. Ghrelin-supported mitochondrial respiration is suggested to inhibit neuronal apoptosis and attenuate reactive oxygen species production (Shi et al. 2017). Previously described ghrelin protective effects against amyloid beta peptide (A $\beta)$ (Martins et al. 2013) and 1-methyl-1,2,3,6 tetrahydropyridine/1-methyl-4-phenylpyridinium ion (MPTP/MPP) toxicity (Jiang et al. 2008) in animal and cell models of $\mathrm{PD}$ and $\mathrm{AD}$, respectively, support this hypothesis (Shi et al. 2017). Moreover, high expression levels of the ghrelin receptor GHS-R1 in the hippocampus, cortex, and substantia nigra (Zigman et al. 2006) support GHS-R1 as a target for treatment of $A D$ and PD.

This study first sought to detect the ghrelin GHS-R1 receptor in SH-SY5Y cells. To evaluate the neuroprotective effects of ghrelin in SH-SY5Y cells, we used a stable ghrelin analog, $\mathrm{Dpr}^{3}$ ghrelin (Dpr ${ }^{3}$ ghr), where octanoic acid was connected to the peptide with a stable amide bond instead of an unstable ester bond, as is the case with natural ghrelin (Bednarek et al. 2000). To further evaluate the neuroprotective effects of ghrelin, we determined the effects of $\mathrm{Dpr}^{3}$ ghr on MG-induced toxicity and SH-SY5Y cell viability and measured the expression of apoptosis-regulating proteins $\mathrm{Bax}$ and Bcl-2 regulated by PKB/Akt and/or MAPK/ERK activation (Salakou et al. 2007).

\section{Materials and Methods}

\section{Peptide synthesis}

The stable analog of ghrelin, $\mathrm{Dpr}^{3}$ ghr [Gly-SerDpr(N-octanoyl)-Phe-Leu-Ser-Pro-Glu-His-Gln-His-Gln-
Lys-Ala-Gln-Gln-ArgLys-Glu-Ser-Lys-Lys-Pro-Pro-AlaLys-Leu-Gln-Pro-Arg], was synthesized and purified at the Institute of Organic Chemistry and Biochemistry, Prague, Czech Republic, as described previously (Maletínská et al. 2012).

\section{Chemicals}

CytoTox 96® NonRadioactive Cytotoxicity Assay kit was purchased from Promega (Madison, WI, USA). MTT (3-[4,5-dimethylthiazol-2-yl]-2,5-diphenyl tetrazolium bromide; thiazolyl blue), methylglyoxal solution $\left(40 \%\right.$ in $\left.\mathrm{H}_{2} \mathrm{O}\right)$, and other common chemicals were obtained from Sigma-Aldrich (St. Louis, MO, USA). Bax, pPKB/Akt(Thr308), pPKB/Akt(Thr473), and PKB/Akt, all rabbit antibodies; pMAPK/ERK, MAPK/ERK, and GAPDH (glyceraldehyde 3-phosphate dehydrogenase), all mouse antibodies; and anti-rabbit IgG HRP-linked antibody and anti-mouse $\operatorname{IgG}$ horseradish peroxidase (HRP)-linked antibody were purchased from Cell Signaling Technology (Beverly, MA, USA). pBcl-2 (phosphoSer70) rabbit antibody was from Biorbyt, LLC (San Francisco, CA, USA), and anti-Ghrelin Receptor Type 1A rabbit antibody was from Merck Millipore (Darmstadt, Germany).

\section{Cell culture}

The SH-SY5Y (ATCC ${ }^{\circledR}$ CRL-2266 ${ }^{\mathrm{TM}}$ ) cell line, obtained from LGC standards (Teddington, UK), was grown in DMEM medium supplemented with $10 \%$ heat-inactivated fetal bovine serum, $1 \%$ non-essential amino acids, $1 \%$ streptomycin/penicillin, and $2 \mathrm{mM}$ L-glutamine at $37^{\circ} \mathrm{C}$ in a humidified atmosphere containing $95 \%$ air $/ 5 \% \mathrm{CO}_{2}$. Medium was changed every 4-5 days, and cells were sub-cultured as required. Control RC-4B/C cells (ATCC® CRL1903) were grown as described previously (Maixnerová et al. 2011).

\section{Cell viability and cytotoxicity measurement}

MTT test was used to measure cell viability, and the CytoTox 96® NonRadioactive Cytotoxicity Assay was used to measure MG induced cytotoxicity. For both assays, cells were cultured in 96-well plates at a density of $4 \times 10^{4}$ cells per well. Growth medium was exchanged for serum-free DMEM medium $16 \mathrm{~h}$ before an experiment. Cells were pre-treated with $1 \times 10^{-5} \mathrm{M}$ or $1 \times 10^{-7} \mathrm{M} \mathrm{Dpr}{ }^{3} \mathrm{ghr}$ (dissolved in serum-free DMEM medium as vehicle) for $4 \mathrm{~h}$ (in quadruplicates); then, the medium was changed. MG was added to a final concentration of $1.2 \mathrm{mM}$, and cells were incubated at 
$37^{\circ} \mathrm{C}$ for $20 \mathrm{~h}$. From each well, $100 \mu \mathrm{l}$ of medium was collected for cytotoxicity measurement using the CytoTox 96® NonRadioactive Cytotoxicity Assay, following the manufacturer's instructions. DMSO (100\%), known for its cytotoxic properties, was used as a comparator for the cytotoxic effects of $\mathrm{MG}$ as it was recommended in the assay.

For cell viability measurements, the MTT reagent dissolved in RPMI-1640 without phenol red was added to cells in the 96-well plate and incubated for $4 \mathrm{~h}$ at $37^{\circ} \mathrm{C}$. Living cells convert soluble MTT to insoluble formazan, which was subsequently dissolved in DMSO. The absorbance was measured at a wavelength of $570 \mathrm{~nm}$.

\section{Western blotting}

GHS-R1 in unstimulated SH-SY5Y cells and Bax, pBcl-2 (Ser70), PKB/Akt, pPKB/Akt (Thr308), pPKB/Akt(Ser473), MAPK/ERK, and pMAPK/ERK in SH-SY5Y cells after a 2-hour-long stimulation with $10^{-5} \mathrm{M} \mathrm{Dpr}{ }^{3} \mathrm{ghr}$ cells, and in unstimulated cells, plated on 6 -well plate at a density $6 \times 10^{5}$ cells per well, were determined by WB. SH-SY5Y cells were washed with cold PBS buffer ( $\mathrm{pH} 7.4$ ), lysed in $400 \mu \mathrm{l}$ of Laemmli sample buffer (62.5 mM Tris-HCl with $\mathrm{pH} 6.8,2 \% \mathrm{SDS}$, $10 \%$ glycerol, $0.01 \%$ bromophenol blue, $5 \%$ $\beta$-mercaptoethanol), and stored at $-20{ }^{\circ} \mathrm{C}$. The cell lysates of $20 \mu \mathrm{l}$ were resolved using $10 \%$ (PKB/Akt, MAPK/ERK), $12 \%$ Ghrelin receptor type 1A, pBcl-2 (Ser70) or $15 \%$ (Bax) SDS-PAGE at $200 \mathrm{~V}$ for $45 \mathrm{~min}$. Resolved proteins were transferred onto a nitrocellulose membrane (Bio-Rad, Hercules, CA USA) in transfer buffer (25 mM Tris, $192 \mathrm{mM}$ glycine, $20 \%$ methanol) at constant voltage of $30 \mathrm{~V}$ for $90 \mathrm{~min}$. Membranes were blocked in $5 \%$ non-fat milk in TBS/Tween-20 buffer (20 mM Tris, $136 \mathrm{mM} \mathrm{NaCl}, 0.1 \%$ Tween-20) and then incubated overnight at $4{ }^{\circ} \mathrm{C}$ in the corresponding antibody diluted following the manufacturer's instructions. Afterward, membranes were incubated for $1 \mathrm{~h}$ in an appropriate anti-mouse or anti-rabbit IgG HRP-linked secondary antibody at room temperature and developed using Luminata Classico/Crescendo/Forte Western HRP Substrates ECL solution (Merck Millipore, Darmstadt, Germany). Chemiluminescence was visualized in a ChemiDoc $^{\mathrm{TM}}$ System (Bio-Rad, Hercules, CA, USA) and quantified using Image Lab Software (Bio-Rad, Hercules, CA, USA). Lysate of pituitary RC-4B/C cells was used as a control for ghrelin receptor type 1A immunodetection and GAPDH served as a loading control for Bax, pBcl-2 (Ser70), PKB/Akt, and MAPK/ERK. The band intensity of each protein of interest was related to the band intensity of the loading control GAPDH. Then, the Bax/Bcl-2 ratio was calculated for $\mathrm{Dpr}^{3} \mathrm{ghr}$ treated cells and untreated controls.

\section{Statistical analyses}

The data are presented as the means \pm SEM and were analyzed with Graph-Pad Software (San Diego, CA, USA) using a one-way ANOVA, followed by a Dunnett's post hoc test, or Student's t-test, as stated in the Figures legends. $\mathrm{P}<0.05$ was considered statistically significant.

\section{Results}

\section{GHS-R1 immunodetection in SH-SY5Y cells}

The immunodetection of GHS-R1 in SH-SY5Y cell lysates showed one major band corresponding to the major band of the $\mathrm{RC} 4 \mathrm{~B} / \mathrm{C}$ cell lysate, the control recommended by the antibody manufacturer for GHS-R1 detection on WB (Fig. 1). The approximate molecular mass of the major GHS-R1 band was $35 \mathrm{kDa}$.

\section{$25 \mathrm{kDa}$ RC-4B/C SH-SY5Y}

Fig. 1. Immunodetection of the ghrelin receptor GHS-R1 in SH-SY5Y cells. Western blot analysis of SH-SY5Y cells and RC-4B/C cell lysates as a GHS-R1-positive control detected with antibody against the GHS-R1 receptor (molecular weight $35 \mathrm{kDa}$ ).

\section{Cell viability and cytotoxicity}

First, MG cytotoxic effects at $1.2 \mathrm{mM}$ concentration in SH-SY5Y cells described earlier (Sharma et al. 2014) was confirmed by us using both MTT and LDH tests. To examine the neuroprotective effect of ghrelin, SH-SY5Y cells were pre-treated with the stable ghrelin analog $\mathrm{Dpr}^{3} \mathrm{ghr}$ at a concentration of $1 \times 10^{-5} \mathrm{M}$ or $1 \times 10^{-7} \mathrm{M}$ for $4 \mathrm{~h}$ and stressed with $1.2 \mathrm{mM}$ MG for $20 \mathrm{~h}$, afterwards.

MG at a concentration of $1.2 \mathrm{mM}$ significantly decreased cell viability compared to control cells in the MTT test (Fig. 2A). Pre-treatment with $\mathrm{Dpr}^{3} \mathrm{ghr}$ prevented MG toxicity in SH-SY5Y cells that resulted in increased cell viability compared to non-pretreated cells (Fig. 2B). 
A

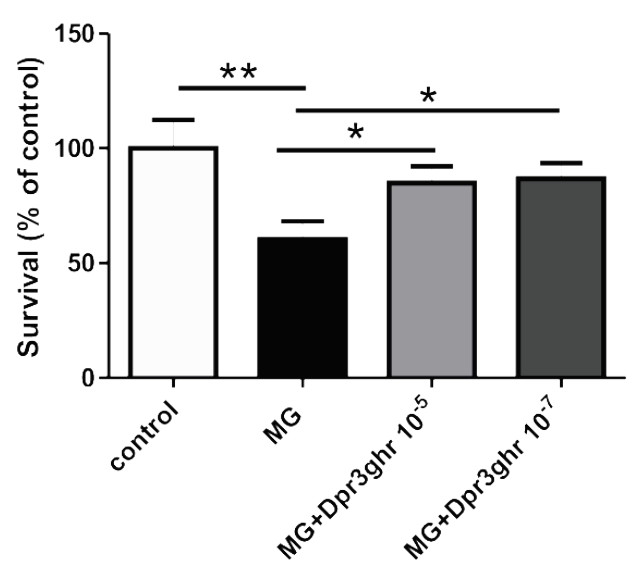

B

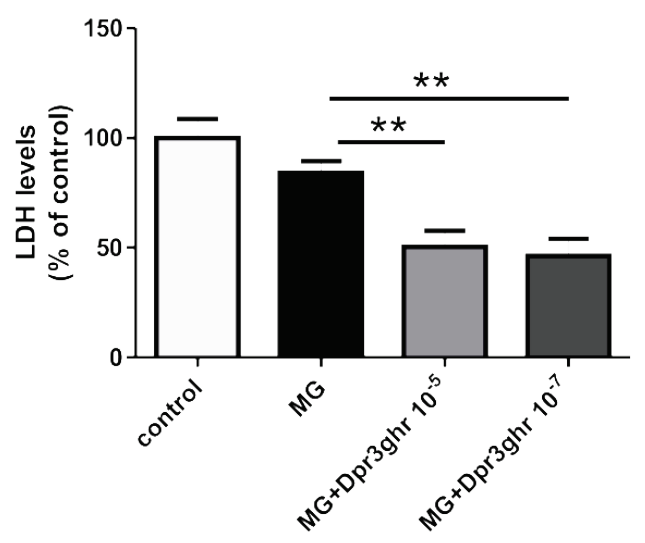

Fig. 2. A. Neuroprotective effects of $D^{2} r^{3}$ ghr against MG-induced cell death. $10^{-7} \mathrm{M}$ and $10^{-5} \mathrm{M} \mathrm{Dpr}^{3} \mathrm{ghr}$ pre-treatment for $4 \mathrm{~h}$, followed by exposure to $1.2 \mu \mathrm{M}$ MG for $20 \mathrm{~h}$ increased cell survival in SH-SY5Y cells as shown by MTT tests. Data are presented as the mean \pm SEM as a percentage of control cells treated with vehicle. Statistics: one-way ANOVA followed by Dunnett post hoc test, $* p<0.5, * * p<0.01 \quad(n=4$; each sample replicated in duplicate). B. Neuroprotective effects of $\mathrm{Dpr}^{3} \mathrm{ghr}$ against MG-induced cell death. $10^{-7} \mathrm{M}$ and $10^{-5} \mathrm{M} \mathrm{Dpr}^{3} \mathrm{ghr}$ pre-treatment for $4 \mathrm{~h}$ followed by exposure to $1.2 \mu \mathrm{M} \mathrm{MG}$ for $20 \mathrm{~h}$ prevented MG-induced increases in levels of lactate dehydrogenase $(\mathrm{LDH})$. Data are presented as the mean \pm SEM as a percentage of control cells treated with DMSO. Data were analyzed by one-way ANOVA followed by Dunnett post hoc test, ${ }^{* *} \mathrm{p}<0.01(\mathrm{n}=4$, each sample replicated in duplicate).

Using the CytoTox 96® NonRadioactive Cytotoxicity Assay, LDH released from dead, lysed cells into the medium was determined. Pre-treatment with Dpr ${ }^{3}$ ghr at both $1 \times 10^{-5} \mathrm{M}$ and $1 \times 10^{-7} \mathrm{M}$ concentrations decreased LDH concentration in the medium that indicated a reversal of cytotoxic effects of $1.2 \mathrm{mM} \mathrm{MG}$ in SH-SY5Y cells that were decreased by 40 and $46 \%$, respectively, compared to MG-treated cells (Fig. 2B). Cytotoxic effects of compounds were normalized to cytotoxic effects of DMSO that was determined as $100 \%$.
Apoptotic markers, PKB/Akt and MAPK/ERK activation

After 2-hour-long $\mathrm{Dpr}^{3} \mathrm{ghr}$ treatment, pro-apoptotic protein Bax was decreased (Fig. 3A), while the active form of pro-viability protein $\mathrm{Bcl}-2$ was increased in Dpr3ghr-treated cells compared to non-treated cells (Fig. 3B). The ratio of $\mathrm{Bax} / \mathrm{Bcl}-2$ decreased to $42 \%$ after $\mathrm{Dpr}^{3}$ ghr treatment compared to controls (Bax decreased to $70 \%$, and Bcl-2 increased to $170 \%$ in $\mathrm{Dpr}^{3} \mathrm{ghr}$ treated cells; the $\mathrm{Bax} / \mathrm{Bcl}-2$ ratio is 0.417), suggesting decreased apoptosis. $\mathrm{Dpr}^{3} \mathrm{ghr}$ significantly increased $\mathrm{PKB} / \mathrm{Akt}$ phosphorylation at Ser473 (Fig. 4). PKB/Akt phosphorylation at Thr308 and phosphorylation of MAPK/ERK following $\mathrm{Dpr}^{3} \mathrm{ghr}$ treatment were not significantly altered (Figs 5 and 6).

\section{Discussion}

To date, ghrelin is the only known natural lipopeptide hormone with octanoyl bound to the hydroxyl of $\mathrm{Ser}^{3}$ via an ester bond.

The ester bond connecting octanoyl to Ser3 is a weak spot in the ghrelin molecule, and its ready hydrolysis results in loss of biological activity (Kojima et al. 1999). Stabilization of the ghrelin molecule was achieved by replacement of the ester bond with an amide bond (Bednarek et al. 2000), resulting in the ghrelin analog $\mathrm{Dpr}^{3}$ ghr. This modification did not affect ghrelin binding, or intracellular calcium elevation in HEK-293 cells expressing human GHS-R1a (Bednarek et al. 2000). In vivo, $\mathrm{Dpr}^{3}$ ghr induced GH secretion in young mice, had prolonged orexigenic effects in adult mice, and increased stability in blood plasma compared to natural ghrelin (Maletínská et al. 2012). Other GHS-R1 agonists show promise as potential drug leads as well. The GHS-R1 agonist macimorelin (Holubová et al. 2013) as a diagnostic test for growth hormone deficiencies in adults is in a phase III clinical study. The GHS-R1 agonist anamorelin (Helsinn) is in phase III clinical studies for treatment of cancer cachexia.

As GHS-R1 is expressed unevenly in the brain, we first immuno-detected GHS-R1 in SH-SY5Y neuroblastoma cells using pituitary RC-4B/C as a control. Ghrelin acts as a growth hormone secretagogue in the pituitary, and GHS-R1 was previously detected in RC-4B/C cells (Falls et al. 2006). The presence of GHS-R1 in SH-SY5Y cells was a pre-requisite for a potential ghrelin effect in neuroblastoma cells. 
Fig. 3. $\mathrm{Dpr}^{3} \mathrm{ghr}$ decreases pro-apoptotic Bax (A) and increases antiapoptotic Bcl-2 (B) in SH-SY5Y cells. a) Western blot analysis of Bax or $\mathrm{BCl}-2$ in SH-SY5Y cells after $2 \mathrm{~h}$ incubation with DMEM medium (control) or $10^{-5} \mathrm{M} \mathrm{Dpr}^{3}$ ghr in DMEM medium. b) Densitometric quantification of the Western blots normalized to GAPDH. Data (percentage of control), presented as mean \pm SEM, were analyzed by Student's t-test, significance is ${ }^{*} \mathrm{p}<0.05$, and $* * p<0.01 \quad(\mathrm{n}=2$, each sample carried out in duplicate).

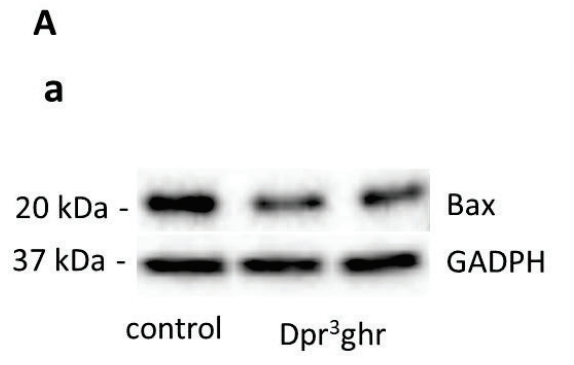

B

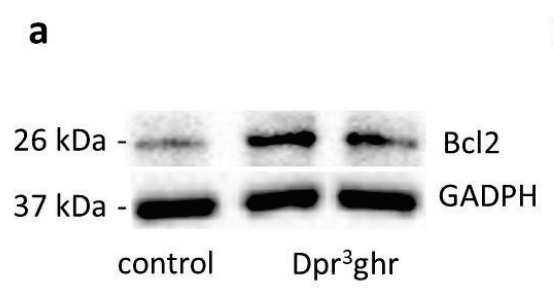

b
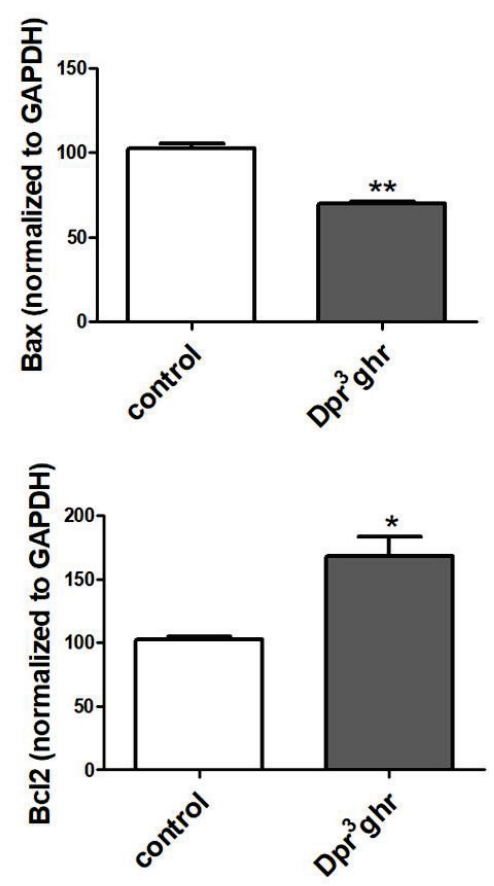

a
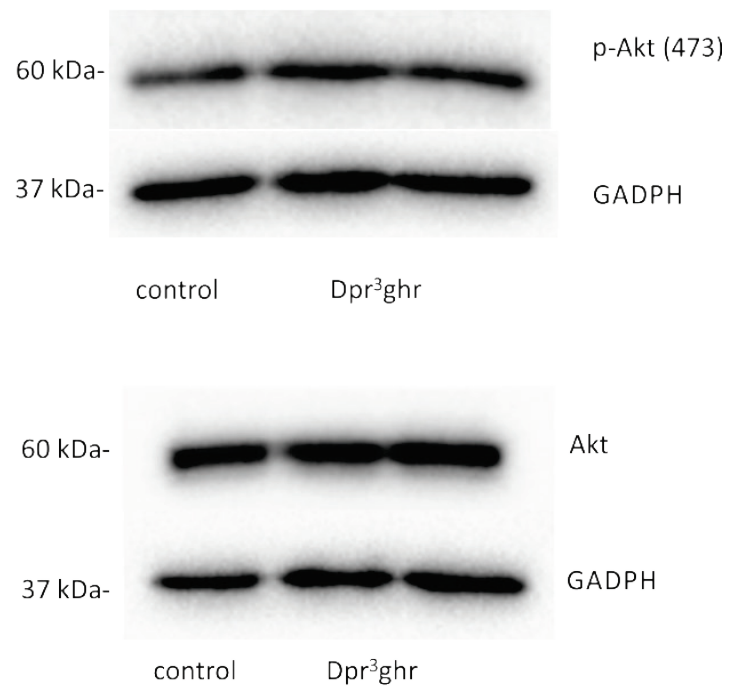

b

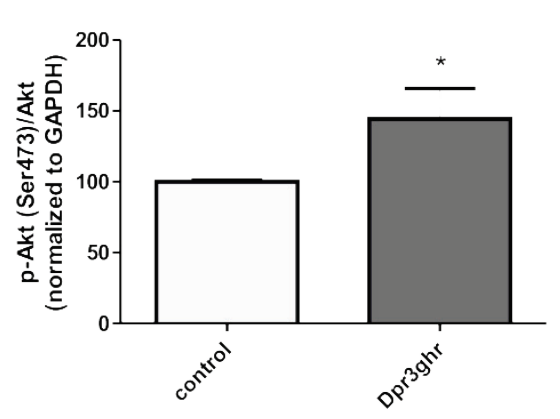

Fig. 4. $\mathrm{Dpr}^{3}$ ghr activates $\mathrm{PKB} / \mathrm{Akt}($ Ser473). a) Western blot analysis of pPKB/Akt(Ser473) in SH-SY5Y cells after $2 \mathrm{~h}$ incubation with DMEM medium (control) or $10^{-5} \mathrm{M} \mathrm{Dpr}^{3} \mathrm{ghr}$ in DMEM medium. b) Densitometric quantification of Western blots normalized to GAPDH. Data (percentage of control), presented as mean \pm SEM, were analyzed by Student's t-test, significance is $*_{p}<0.05$ ( $n=2$, each sample carried out in duplicate). a

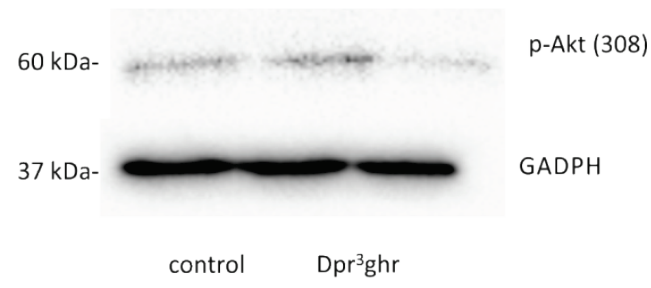

b

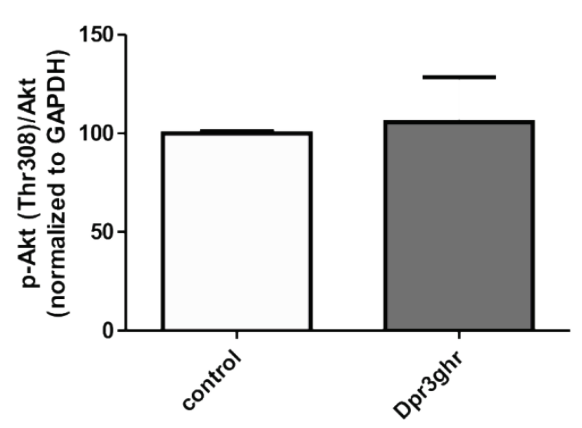

Fig. 5. $\mathrm{Dpr}^{3}$ ghr non-significantly increases PKB/Akt(Thr308). a) Western blot analysis of pPKB/Akt(Thr308) in SH-SY5Y cells after $2 \mathrm{~h}$ incubation with DMEM medium (control) or $10^{-5} \mathrm{M}$ $\mathrm{Dpr}^{3} \mathrm{ghr}$ in DMEM medium. b) Densitometric quantification of Western blots normalized to GAPDH. Data (percentage of control), presented as mean \pm SEM, were analyzed by Student's $\mathrm{t}$-test ( $\mathrm{n}=2$, each sample carried out in duplicate). 
a

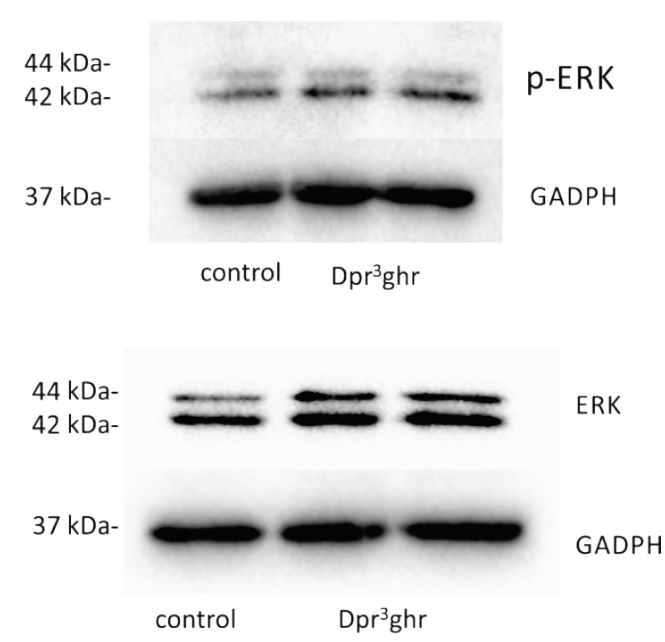

b

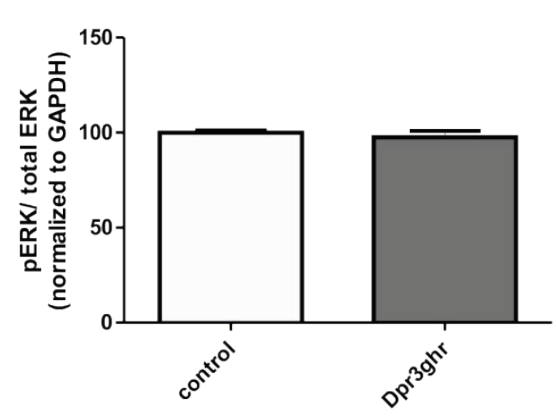

Fig. 6. $\mathrm{Dpr}^{3} \mathrm{ghr}$ does not change MAPK/ERK phosphorylation. a) Western blot analysis of MAPK/ERK phosphorylation in SH-SY5Y cells after $2 \mathrm{~h}$ incubation with DMEM medium (control) or $10^{-5} \mathrm{M} \mathrm{Dpr}^{3} \mathrm{ghr}$ in DMEM medium. b) Densitometric quantification of Western blots normalized to GAPDH. Data (percentage of control), presented as mean \pm SEM, were analyzed by Student's t-test $(n=2$, each sample carried out in duplicate).
Similarly, as in the study with the GLP-1 analog liraglutide (Sharma et al. 2014) where liraglutide enhanced cell viability in tetrazolium dye (XTT) proliferation assays and attenuated MG cytotoxicity in LDH assays, Dpr ${ }^{3}$ ghr in MG-stressed SH-SY5Y cells increased viability determined by the MTT test. We used the MTT viability test and not a XTT proliferation test because we considered viability of adult cells evidence of neuroprotective properties of $\mathrm{Dpr}^{3} \mathrm{ghr}$, rather than proliferation of tumor SH-SY5Y cells. Pre-treatment of SH-SY5Y by Dpr3ghr at both concentrations prevented the cytotoxic effects of MG, which was determined by LDH concentration in medium.

To explain $\mathrm{Dpr}^{3} \mathrm{ghr}$ neuroprotective effects on SH-SY5Y cells, we found changes in pro-apoptotic Bax that were attenuated by $\mathrm{Dpr}^{3} \mathrm{ghr}$ and production of pro-viability protein Bcl-2 that was enhanced by $\mathrm{Dpr}^{3} \mathrm{ghr}$. The Bax/Bcl-2 ratio was lowered by $\mathrm{Dpr}^{3}$ ghr treatment.

Even though both liraglutide and ghrelin activate MAPK/ERK, we did not detect MAPK/ERK phosphorylation following $\mathrm{Dpr}^{3} \mathrm{ghr}$ treatment. On the other hand, we detected ghrelin-induced PKB/Akt phosphorylation (Ser473), which was linked to survival and inhibition of apoptosis in SH-SY5Y cells (Sharma et al. 2014). As ghrelin also activates $\mathrm{Ca}^{2+}$ influx and AMPK, its activation pathways in SH-SY5Y could be rather complicated. Scheme of suggested mechanism of the $\mathrm{Dr}^{3}$ ghr effect on apoptosis is depicted in Figure 7.

In conclusion, we clearly demonstrated that $\mathrm{Dpr}^{3}$ ghr, a stable ghrelin analog, is neuroprotective against

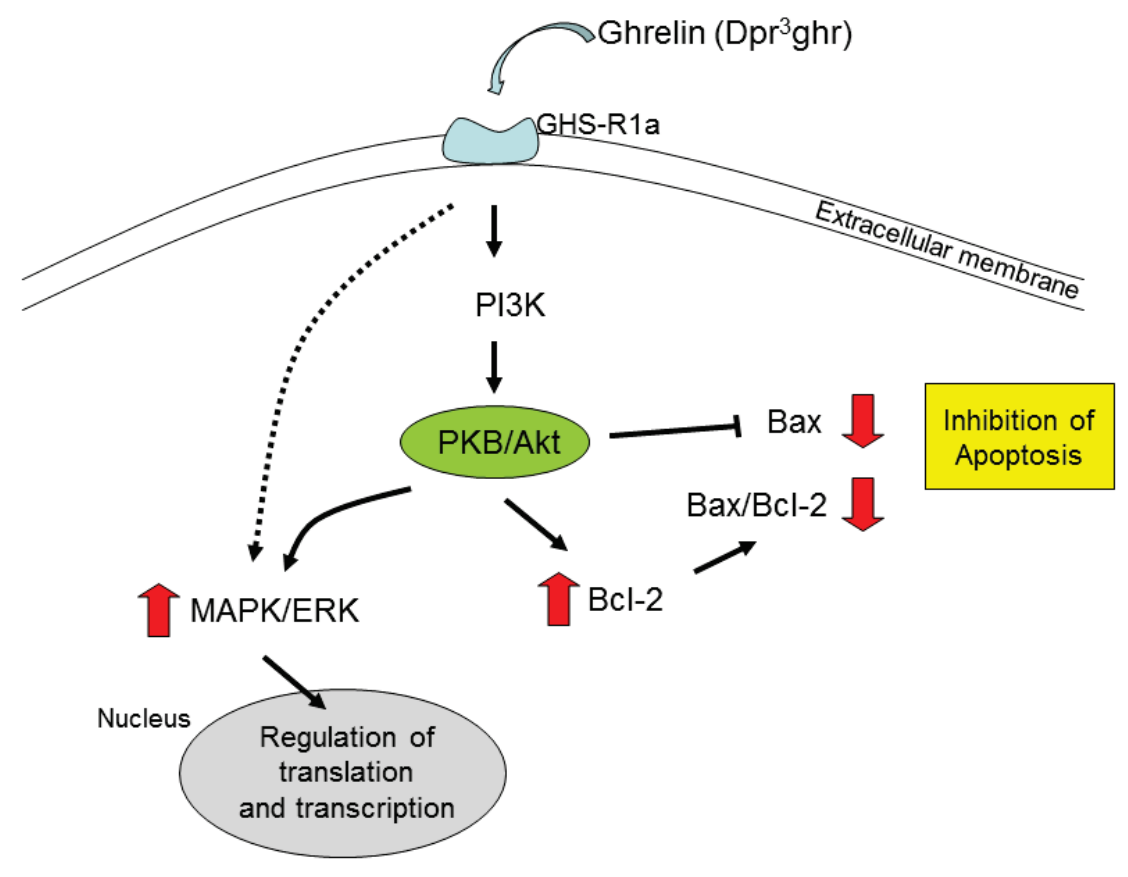

Fig. 7. Scheme of suggested mechanism of Dpr $^{3}$ ghr's anti-apoptotic effect. The potential pathways are mediated by PKB/Akt and MAPK/ERK pathways. GHS-R1a - ghrelin receptor, PI3K - phosphoinositide 3 kinase, PKB - protein kinase B, MAPK - mitogenactivated protein kinase, ERK extracellular signal-regulated kinase. 
methylglyoxal toxicity in SH-SY5Y cells, where it demonstrated anti-cytotoxic, pro-viability, and antiapoptotic effects. These data suggest that stable ghrelin analogs hold potential for the treatment of neurodegenerative diseases.

\section{Conflict of Interest}

There is no conflict of interest.

\section{Acknowledgements}

This study was supported by grant No. 16-00918S of the Grant Agency of the Czech Republic and RVO: 61388963 and RVO:67985823 of the Academy of Sciences of the Czech Republic. Authors would like to thank M. Blechová for synthesis of the ghrelin analog.

\section{References}

AMICARELli F, COLAFARINA S, CATTANI F, CIMINI A, Di ILIO C, CERU MP, MIRANDA M: Scavenging system efficiency is crucial for cell resistance to ROS-mediated methylglyoxal injury. Free Radic Biol Med 35 : 856-871, 2003.

BEDNAREK M, FEIGHNER S, PONG S, MCKEE K, HRENIUK D, SILVA M, WARREN V, HOWARD A, VAN DER PLOEG L, HECK J: Structure-function studies on the new growth hormone-releasing peptide, ghrelin: minimal sequence of ghrelin necessary for activation of growth hormone secretagogue receptor 1a. J Med Chem 43: 4370-4376, 2000.

D'AMELIO M, CAVALLUCCI V, MIDDEI S, MARCHETTI C, PACIONI S, FERRI A, DIAMANTINI A, DE ZIO D, CARRARA P, BATTISTINI L, MORENO S, BACCI A, AMMASSARI-TEULE M, MARIE H, CECCONI F: Caspase-3 triggers early synaptic dysfunction in a mouse model of Alzheimer's disease. Nat Neurosci 14: 69-76, 2011.

DE ARRIBA SG, STUCHBURY G, YARIN J, BURNELL J, LOSKE C, MUNCH G: Methylglyoxal impairs glucose metabolism and leads to energy depletion in neuronal cells-protection by carbonyl scavengers. Neurobiol Aging 28: 1044-1050, 2007.

FALLS H, DAYTON B, FRY D, OGIELA C, SCHAEFER V, BRODJIAN S, REILLY R, COLLINS C, KASZUBSKA W: Characterization of ghrelin receptor activity in a rat pituitary cell line RC-4B/C. J Mol Endocrinol 37: 51-62, 2006.

HOLUBOVÁ M, ŠPOLCOVÁ A, DEMIANOVÁ Z, SÝKORA D, FEHRENTZ JA, MARTINEZ J, STOFKOVÁ A, JURČOVIČOVÁ J, DRÁPALOVÁ J, LACINOVÁ Z, HALUZÍK M, ŽELEZNÁ B, MALETÍNSKÁ L: Ghrelin agonist JMV 1843 increases food intake, body weight and expression of orexigenic neuropeptides in mice. Physiol Res 62: 435-444, 2013.

JIANG H, LI L, WANG J, XIE J: Ghrelin antagonizes MPTP-induced neurotoxicity to the dopaminergic neurons in mouse substantia nigra. Exp Neurol 212: 532-537, 2008.

KOJIMA M, HOSODA H, DATE Y, NAKAZATO M, MATSUO H, KANGAWA K: Ghrelin is a growth-hormonereleasing acylated peptide from stomach. Nature 402: 656-660, 1999.

MAIXNEROVÁ J, ŠPOLCOVÁ A, PÝCHOVÁ M, BLECHOVÁ M, ELBERT T, REZÁČOVÁ M, ZELEZNÁ B, MALETÍNSKÁ L: Characterization of prolactin-releasing peptide: binding signaling and hormone secretion in rodent pituitary cell lines endogenously expressing its receptor. Peptides 32: 811-817, 2011.

MALETÍNSKÁ L, PÝCHOVÁ M, HOLUBOVÁ M, BLECHOVÁ M, DEMIANOVÁ Z, ELBERT T, ŽELEZNÁ B: Characterization of new stable ghrelin analogs with prolonged orexigenic potency. J Pharmacol Exp Ther 340: 781-786, 2012.

MARTINS I, GOMES S, COSTA RO, OTVOS L, OLIVEIRA CR, RESENDE R, PEREIRA CM: Leptin and ghrelin prevent hippocampal dysfunction induced by Abeta oligomers. Neuroscience 241: 41-51, 2013.

SALAKOU S, KARDAMAKIS D, TSAMANDAS AC, ZOLOTA V, APOSTOLAKIS E, TZELEPI V, PAPATHANASOPOULOS $\mathrm{P}$, BONIKOS DS, PAPAPETROPOULOS $\mathrm{T}$, PETSAS T, DOUGENIS D: Increased $\mathrm{Bax} / \mathrm{Bcl}-2$ ratio up-regulates caspase-3 and increases apoptosis in the thymus of patients with myasthenia gravis. In Vivo 21: 123-132, 2007.

SHARMA MK, JALEWA J, HOLSCHER C: Neuroprotective and anti-apoptotic effects of liraglutide on SH-SY5Y cells exposed to methylglyoxal stress. J Neurochem 128: 459-471, 2014. 
SHI L, DU X, JIANG H, XIE J: Ghrelin and neurodegenerative disorders - a review. Mol Neurobiol 54: 1144-1155, 2017.

TAJES M, ERASO-PICHOT A, RUBIO-MOSCARDO F, GUIVERNAU B, BOSCH-MORATO M, VALLSCOMAMALA V, MUNOZ FJ: Methylglyoxal reduces mitochondrial potential and activates Bax and caspase-3 in neurons: implications for Alzheimer's disease. Neurosci Lett 580: 78-82, 2014.

ZIGMAN JM, JONES JE, LEE CE, SAPER CB, ELMQUIST JK: Expression of ghrelin receptor mRNA in the rat and the mouse brain. J Comp Neurol 494: 528-548, 2006. 